\title{
Cetacean Presence in the Trincomalee Bay and Adjacent Waters, Sri Lanka
}

\author{
Ranil P. Nanayakkara, ${ }^{1,2,3}$ Jayampathi Herath, ${ }^{2,4,5}$ and Ruvinda K. de $\mathrm{Mel}^{2}$ \\ ${ }^{1}$ Department of Zoology, University of Kelaniya, 11600 Kelaniya, Sri Lanka \\ ${ }^{2}$ BEAR (Biodiversity Education and Research), No. 4, Dr. E. W. Adikaram Mawatha, 10100 Pita Kotte, Sri Lanka \\ ${ }^{3}$ IUCN-Sirenian Specialist Group, Regional Member (Indian Ocean), Sri Lanka \\ ${ }^{4}$ Postgraduate Institute of Science (PGIS), University of Peradeniya, 20400 Peradeniya, Sri Lanka \\ ${ }^{5}$ Department of Biology and Ecology, Faculty of Medicine, South Asian Institute of Technology and Medicine, 10115 Malabe, Sri Lanka
}

Correspondence should be addressed to Jayampathi Herath; jayampathi_herath@yahoo.com

Received 31 May 2014; Revised 3 September 2014; Accepted 17 September 2014; Published 21 October 2014

Academic Editor: Judith S. Weis

Copyright ( 2014 Ranil P. Nanayakkara et al. This is an open access article distributed under the Creative Commons Attribution License, which permits unrestricted use, distribution, and reproduction in any medium, provided the original work is properly cited.

\begin{abstract}
In Sri Lanka thirty species of cetaceans have been recorded to date. The canyon at Trincomalee bay is a multiple submarine canyon complex and anecdotal reports suggest that the Trincomalee bay and its adjacent waters are utilised by a number of cetacean species. Though Cetaceans are known to be abundant in the waters off Trincomalee there is a dearth of research and data pertaining to the abundance and species frequenting the Trincomalee bay and its adjacent waters. As such the current study was initiated, to get a consensus of the abundance and occurrences of species in Trincomalee Bay and its adjacent waters. Field surveys were carried out for 19 months and the research platform was a 35-foot commercial fishing vessel. 177 cetacean encounters were recorded on 67 of the 75 field days. Remarkably a total of 11 species of cetaceans which composed of two species of Baleen Whales and nine species of Toothed Whales were recorded. Delphinidae was the most common family recorded, followed by Balaenopteridae, Ziphiidae, Physeteridae, and Kogiidae. Spinner Dolphins were the most abundant cetacean owing to the large pods observed and the regularity of the sightings. They were the only species seen feeding/traveling with birds and fish (tuna). Sperm Whales, Blue Whales, and Bryde's Whales were also relatively common. Two records of interspecific association between cetaceans were recorded. The increase in the human population in the study area has resulted in the overexploitation of marine resources which has dire repercussions on the marine mammal communities found in these waters.
\end{abstract}

\section{Introduction}

Sri Lanka is situated between $5^{\circ}$ and $10^{\circ}$ of the equator, south of the Indian subcontinent, and has a land area of $65245 \mathrm{~km}^{2}$. Sri Lanka's territorial waters are rich in marine mammal fauna with high species richness and year-round abundance. Thirty species of cetaceans have been recorded to date. Of the 30 species, 29 belong to the Order Cetartiodactyla, are placed within the two Suborders Mysticeti and Odontoceti, and come under the six Families of Balaenopteridae, Physeteridae, Kogiidae, Ziphiidae, Delphinidae, and Phocoenidae [1]. The single species in the Order Sirenia is the Dugong (Dugong dugon), belonging to the Family Dugongidae [2].
The current study was carried out as a feasibility study to assess the general cetacean community within the Trincomalee bay and its adjacent waters. As there has been a dearth of research into cetacean communities and their occurrence off the east coast of Sri Lanka with the exception of Dayaratne and Josheph 1993, carried out a survey on dolphin catches in Sri Lanka. The lack of such dedicated surveys was due to the hostility (terrorist war) that prevailed in that part of the country for the past 30 years. The waters of Trincomalee are utilised by a number of cetacean species. Some species pass through the bay intermittently or while on migration, whilst other species appear to be resident or semi-resident in the bay. Anecdotal reports suggest that the waters of 


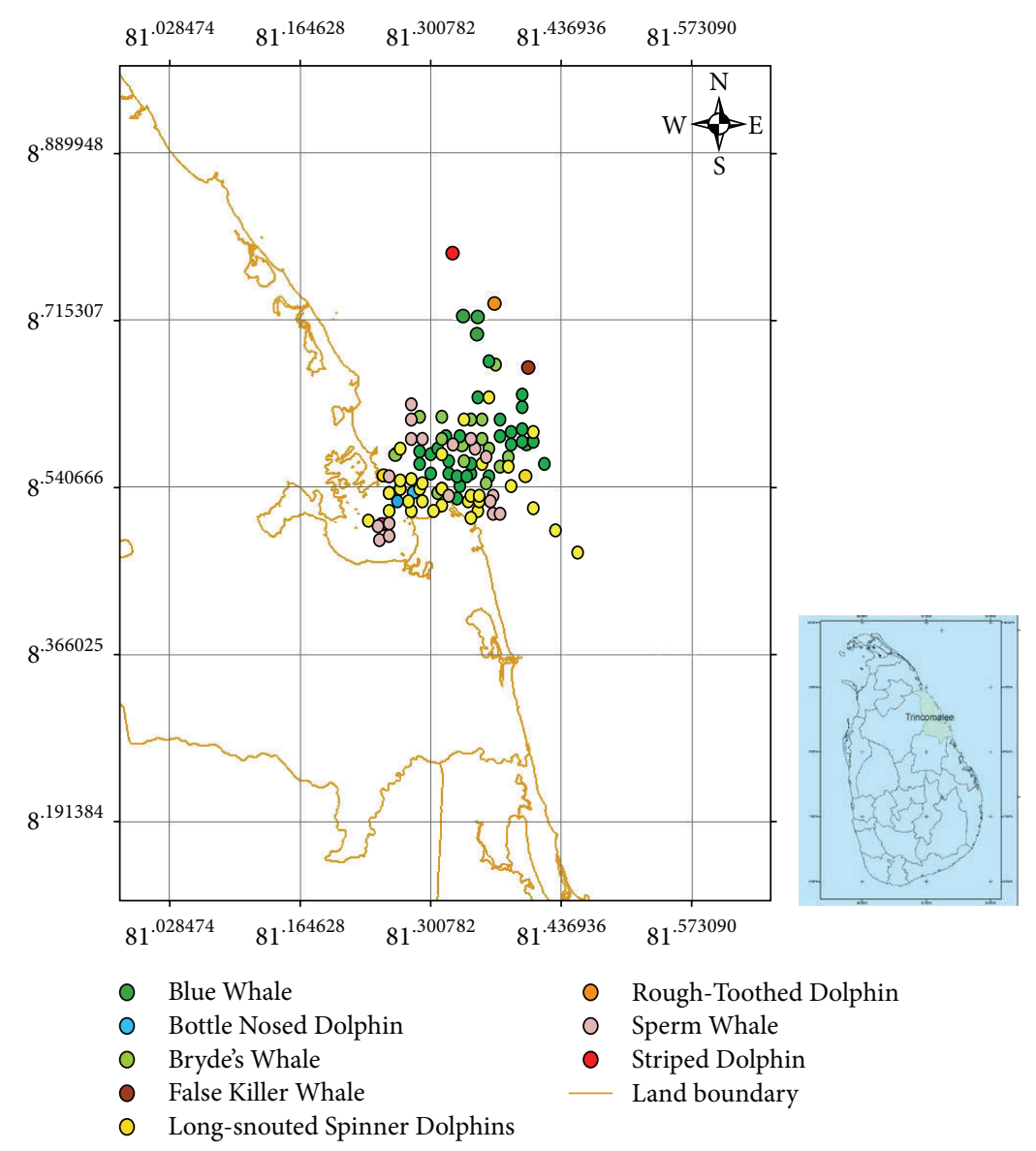

FIGURE 1: Locations of sightings of the cetacean species in Trincomalee bay and adjacent waters.

Trincomalee are frequented by large numbers of cetaceans. Though whale watching is carried out on a commercial scale, most observers on these expeditions do not keep a log of the species encountered and the identification of species is abysmal. As such monitoring cetacean populations is crucial for understanding the changes occurring over time, including the extent of geographic occurrence and shift in species composition.

While a comprehensive and dedicated effort would be needed to assess cetacean abundance and gain insight into the population status and trend, datasets such as the one presented here are relevant to understanding shifts in species composition and patterns of distribution. Thus, studies such as this, though very limited, provide baseline data for future studies on cetaceans off the East coast of Sri Lanka. Herewith we present data obtained through vessel based surveys conducted in Trincomalee bay and its adjacent waters, to record the occurrence and species richness of cetacean.

\section{Material and Methods}

2.1. Study Site. Trincomalee is located in the east coast of Sri Lanka (Figure 1). The canyon at Trincomalee is a multiple submarine canyon complex, the largest in the country, and one of the twenty largest submarine canyons in the world.

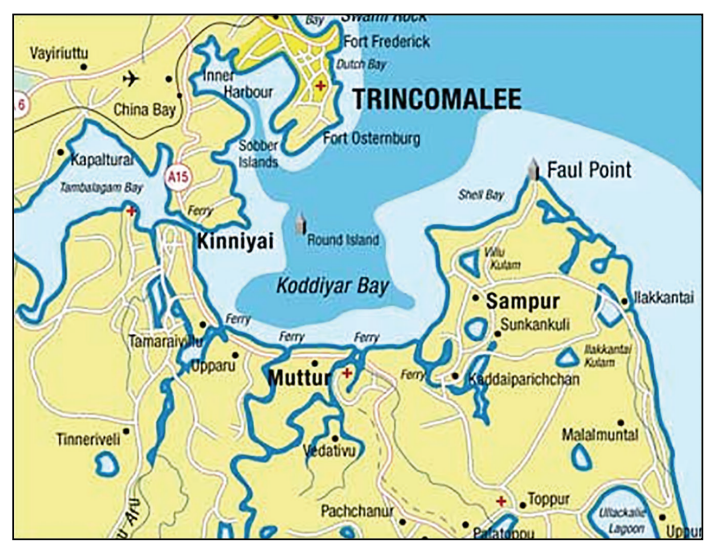

Figure 2: Map of Trincomalee bay.

The canyon commences today in Koddiyar and Trincomalee bays (Figure 2). The canyon has walls 1350 metres high, of hard granitic and quartzitic rocks [3]. It can be traced seawards as a gorge for over $60 \mathrm{~km}$ and down to depth over $3350 \mathrm{~m}$ and 3600 as a fan valley with natural levees in debris [4]. The Trincomalee canyon is created by the runoff from the largest river in Sri Lanka the Mahaweli. The mean salinity recorded from Trincomalee bay and its 
adjacent waters during the study period was $28.1 \pm 4.8 \mathrm{ppt}$ while the mean temperature was recorded as $28.81 \pm 0.96^{\circ} \mathrm{C}$ (unpublished data).

The rocky sea bed of Trincomalee supports extensive reef habitats, the majority of which are large boulder type reefs of crystalline rock [5]. These elements coupled together with the runoff of the Mahaweli River makes the Trincomalee bay and its adjacent waters very rich in marine fauna and flora. As such, it is heavily exploited by fisher, as these waters are very productive.

2.2. Survey Methodology. Boat surveys were conducted during 75 field days (days out at sea) evenly spaced out over a 19-month period, weather-dependent field season starting in July 2010 and ending in January 2012. The research platform was a 35-foot commercial fishing vessel. The vessel generally ran 12-hour trips from 06:00 hrs to 18:00 hrs. The cruising speed was about $10 \mathrm{~km}$ an hour. Survey trips were occasionally cancelled due to adverse weather and/or sea conditions. The transect was standard line transect. Two points were chosen to start the line transect; namely, foul point on the right side and chapel rock on the left of the bay were selected as the main starting points and ten nautical miles were traversed in a zig zag pattern while going out of the bay and returning back. This was considered as a transect; during which cetacean sightings were systematically recorded.

Four trained observers recorded sightings from amidships to the bow, one looking to port and the other to starboard. They searched for cetaceans $50 \%$ by eye and $50 \%$ using $7 \times 50$ Bushnell binoculars. The binoculars were used when a blow or a pod of cetaceans were sighted at a distance. The search efforts were occasionally interrupted when a pod or an individual cetacean was sighted, as the observers tried to determine the species. Data on effort included date, start time/end time, GPS position, and sea condition.

Data on cetacean sightings included the species and group size. As the encounter rate was of interest, a precise estimate of the distance of the species from the boat was not necessary. A cetacean sighting was defined as a single animal or a group of animals of one species within a radius of $100 \mathrm{~m}$ for dolphins or $1 \mathrm{~km}$ for whales; however, no association between individuals in a group was inferred. Maximum, minimum, and best estimates of group size were recorded for each sighting. The surveys were only carried out under Beaufort $<3$. Search efforts ceased during bad weather namely, rain, strong winds, and high sea state. When possible, the encountered species were photographed using a Nikon D90 camera fitted with a $300 \mathrm{~mm}$ zoom lens.

\section{Results and Discussion}

The overall observation effort was $804 \mathrm{~h}$ accomplished during the survey period, covering almost $2700 \mathrm{~km}$ of sea. 215 cetacean encounters were recorded on 67 of the 75 field days (Table 1, Figure 3). A total of 11 species of cetaceans were positively identified. The identified species included two species of Baleen Whales (Mysticeti), namely, Blue Whale (Balaenoptera musculus), Bryde's Whale (Balaenoptera edeni), and

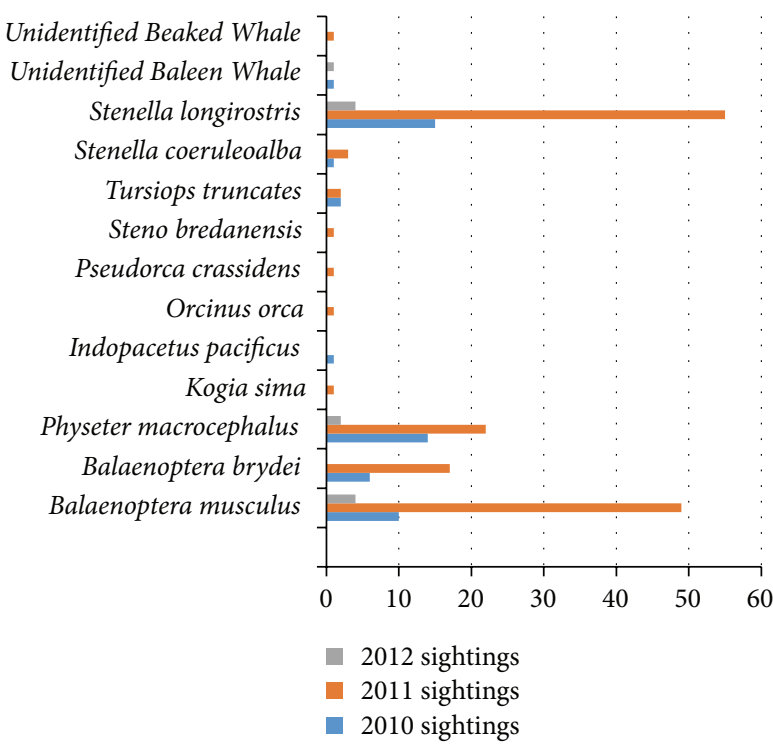

FIGURE 3: No. of sightings of individual species per year.

nine species of Toothed Whales (Odontoceti), namely, Sperm Whale (Physeter macrocephalus), Killer Whale (Orcinus orca), Dwarf Sperm Whale (Kogia sima), Longman's Beaked Whale (Indopacetus pacificus), False Killer Whale (Pseudorca crassidens), Rough-Toothed Dolphin (Steno bredanensis), Bottlenose Dolphin (Tursiops truncates), Striped Dolphin (Stenella coeruleoalba), and Spinner Dolphin (Stenella longirostris). Three unidentified cetaceans were recorded, two Baleen Whales and one Beaked Whale. Species level identification was not possible on the three sightings due to the distance and short duration of the sightings. Delphinidae was the most common family recorded, followed by Balaenopteridae, Ziphiidae, Physeteridae, and Kogiidae.

The Spinner Dolphins were the most abundant cetacean owing to the large size of the pods observed and the regularity of the sightings. Sperm Whales, Blue Whales, and Bryde's Whales were also relatively common, although in much fewer numbers; however two sightings of large super pods of Sperm Whales, consisting of 50 plus individuals, were recorded. Occasional sightings were recorded of Bottlenose Dolphins, Striped Dolphin, with sporadic records of a Killer Whale, Rough-Toothed Dolphins, Longman's Beaked Whales, Dwarf Sperm Whale, and False Killer Whales. The sighting of the Killer Whale is a rarity in Sri Lankan waters; however, current records indicate the yearly presence of a few photo identified individuals of Killer Whales around Sri Lankan waters.

\subsection{Species Accounts}

3.1.1. Blue Whale (Balaenoptera musculus). A total of 63 Blue Whales sightings were recorded over the survey period, out of which only three animals were photo-identified by individual markings, namely, the tail and the dorsal fin and the depigmentation marking close to the dorsal fin. These were added to a catalog of blue whales currently being developed. 


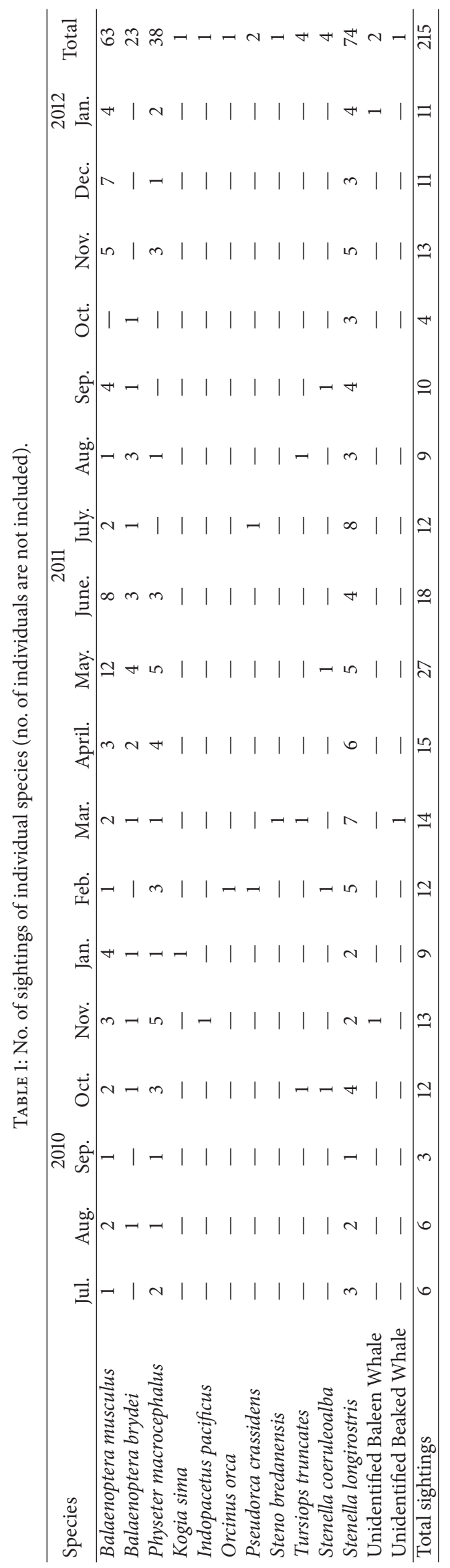


Blue Whales were sighted in almost all months of the survey period $(n=63)$ apart from October 2011. They were frequently seen during the months of May and June. One large aggregation was recorded in May 2011, where eight animals were seen in an area of approximately $1 \mathrm{~km}, 10 \mathrm{~nm}$ out at sea (Figure 1). Other than this isolated record, they were predominately seen alone, or in loose aggregation, where the animals were always one nautical mile apart. No clear associations were made between any adult whales. On several occasions blue whale defecation was observed near swami rock, giving the notion that they were feeding in the waters of Trincomalee bay.

The Blue Whales were mostly sighted opposite swami rock in the morning hours between 6:00-8:00 and moved farther off shore between 8-10 nautical miles as the day proceeded and inhabited that area temporarily, moving further out to deep sea after 13:00 hours.

The Blue Whales were observed diving on many occasions and each time they fluked before diving. On several occasions they were observed bobbing up and down in one place. One individual appeared very thin: the dorsal processes of the vertebral column were clearly visible projecting along the back anterior to the dorsal fin.

3.1.2. Bryde's Whale (Balaenoptera edeni). A total of 23 Bryde's Whales were encountered, close to foul point and swami rock. They were easily identified by the three rostral ridges. The highest encounter rate for Bryde's Whales was in the months of April, May, and June with May recording the highest number (4). Other than a suspected female and calf pair, they were predominately seen alone.

No feeding behaviour was observed. On one occasion one individual Bryde's Whale was seen in association with Spinner Dolphins.

3.1.3. Sperm Whale (Physeter macrocephalus). Sperm whales were recorded in almost all months during the survey except June, September, and October 2011, respectively (Table 1, Figure 3). The sightings of sperm whales were widely distributed, with some occurring inside the bay, particularly around Round Island.

They were observed diving, with dives inside the bay lasting about 10 mins. However, the pods observed inside the bay only consisted of 8-10 animals.

On two occasions super pods were recorded consisting of over 50 individuals in each pod. The super pods were recorded in February 2011 and April 2011. They were observed milling, tail slapping, and logging. On both occasions they were observed travelling in a northeastern direction towards Mullaitivu. On several occasions the authors have observed large super pods of Sperm Whales off the Mullaitivu canyon.

3.1.4. Dwarf Sperm Whale (Kogia sima). One individual was observed about 7 nautical miles out at sea; it was seen logging at the surface. It dove as soon as the vessel was within 200 metres of the animal. It was set apart from the pygmy Sperm Whale (Kogia breviceps) by the dorsal fin being more pronounced.
3.1.5. Longman's Beaked Whale (Indopacetus pacificus). Four individuals were sighted about 9 nautical miles out at sea, from swami rock; they were traveling in a northeasterly direction. They were about 200 metres from the boat. They suddenly surfaced from the depths. They were spotted by the observer at the bow. No sooner they noticed the boat they dove and resurfaced about 200 metres away from the boat. Their estimated lengths were from $6.7 \mathrm{~m}$ to $7 \mathrm{~m}$, and they appeared grayish in colour, with a pronounced bulbous head; the head area was lighter. It was easily identified as the Longman's Beaked Whale, as there are only four species of Beaked Whales so far recorded from Sri Lanka and Longman's Beaked Whale is the only species that grow that large and who has a bulbous melon.

3.1.6. Killer Whale (Orcinus orca). One animal was seen travelling in souther direction about 5 nautical miles from foul point. It was swimming quite fast.

3.1.7. False Killer Whale (Pseudorca crassidens). Two pods of False Killer Whales were observed $(n=15)$ : one pod consisted of seven animals and the other of eight animals. They were observed in February 2011 and July 2011, respectively. They were seen traveling about 7 nautical miles out at sea. No association with other cetaceans was observed. The pods seemed to take no interest in our vessel. The sighting of False Killer Whales was considered as two pods due to them being oceanic and the lack of one animal in the latter sighting. False Killer Whales are known to form strong social bonds within their cohesive pods.

3.1.8. Bottlenose Dolphin (Tursiops truncatus). Bottlenose Dolphins were sighted on five occasions $(n=25)$. On two occasions they were observed near Round Island at $6: 45 \mathrm{~h}$ and 7:32 h, respectively. In the latter encounter one individual was seen lobtailing. Their blows are loud when compared to other dolphins. The two pods consisted of 5 and 6 individuals, respectively.

The other two sightings were near swami rock, which consisted of five and seven individuals. The fifth encounter was of two animals about 3 nautical miles off foul point, in close association with a pod of Spinner Dolphins. However, they were about 10 meters away from the pod of Spinners and they were following the Spinners. Behaviour recorded included bow riding, head-first-reentry jumps, back-slaps, head-slaps, leaps, lob tailing, and tail slaps.

3.1.9. Rough-Toothed Dolphin (Steno bredanensis). RoughToothed Dolphins are relatively rare in Sri Lankan waters. They were observed near a floating buoy. They were seen diving and surfacing near the buoy. This type of association with floating objects has been noted by Pitman and Stinchcomb [6] and Anderson [7]. The Rough-Toothed Dolphins were encountered in March $2011(n=7)$. Out of the seven encountered, two individuals had extensive depigmentation.

3.1.10. Striped Dolphin (Stenella coeruleoalba). Striped Dolphins were encountered in October 2010, February 2011, May 
2011, and September 11, respectively $(n=200)$. They were always observed out in deep sea, about 7-10 nautical miles out at sea. They were recorded in large pods consisting of approximately 40 animals; one pod that was encountered in September consisted of well over 70 individuals. However, a consensus could not be made, as to how many animals were actually in the pod. The latter pod was in association with Spinner Dolphins. Both species displayed acrobatic behaviour. Aerial activity included head slap, back slap, and leaps.

3.1.11. Spinner Dolphin (Stenella longirostris). The Spinner Dolphin was by far the most frequently observed species of cetacean during the survey; they were seen in all months over the sampling period ( $n \geq 1000)$. Spinner Dolphins were observed close to shore at the beginning of the bay. They were frequently seen between swami rock and foul point. Almost all sightings of this species were associated with large Yellowfin Tuna (Thunnus albacares, 70\%). Local fishermen have taken advantage of this association to locate Yellowfin Tuna and catch the Tuna using the highly visible pods of dolphins. The Yellowfin Tuna is caught using hook and line. The association between Dolphin and Tuna in Sri Lankan waters is restricted to Yellowfin Tuna. This was intimated to the research team by the fisher. This was evident by our observations of fisher using hook and line to catch large Yellowfin Tuna. The association between Yellowfin Tuna and other species of dolphins, such as Spotted Dolphins, has been recorded in the eastern tropical Pacific and the western tropical Indian Ocean $[8,9]$.

As mentioned earlier the Spinners were observed in association with Striped Dolphins on one occasion. On several occasions Spinner Dolphins were observed bow riding, breaching, and spinning in the air.

In the morning from 6:00 to $9: 00 \mathrm{~h}$ they were seen between foul point and swami rock, after which they go farther out to deep sea, to return back toward swami rock, towards dusk around 16:00 to 18:00 h.

3.2. Unidentified Baleen Whale and Beaked Whale. Two unidentified Baleen Whales and one Beaked Whale were recorded during the survey. The discrepancy in the identification of the species was due to the distance and sea condition the animals were recorded at. The Beaked Whale looked dark brown in colour and it did not fluke but rather arched its back when diving.

3.3. Interspecific Association. Out of 215 sightings of cetaceans only on three occasions was interspecific association between cetaceans recorded in the Trincomalee canyon and its adjacent waters. Association between Spinner Dolphins and Striped Dolphins $(n>400)$ was recorded about seven nautical miles out at sea. The other record was with Spinners and Bottlenose Dolphins. Two Bottlenose Dolphins were following a large pod of Spinners, lagging about 10 metres behind the Spinners. A Bryde's Whale was observed in association with Spinner Dolphins, one nautical mile off foul point toward the open sea.
Total number of individuals observed

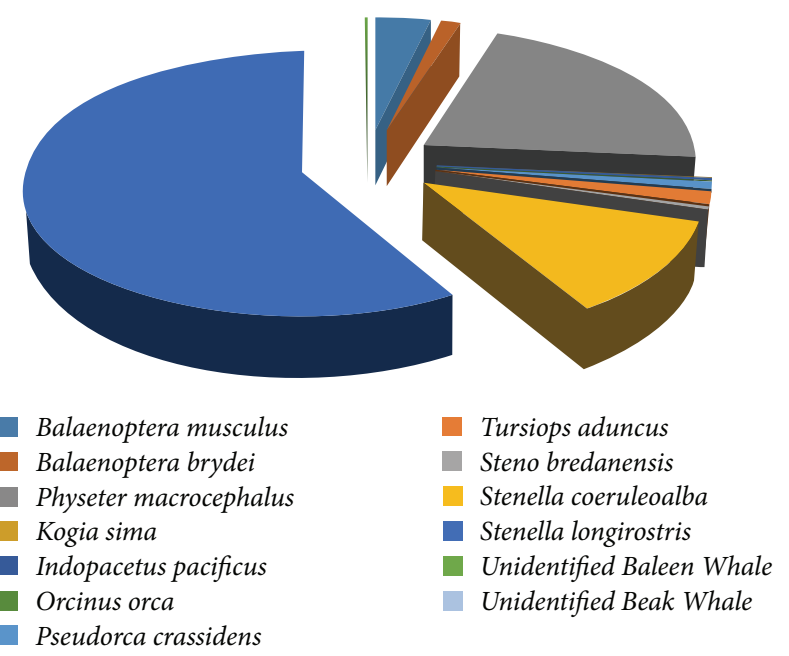

FIgURE 4: Total no. of individuals observed.

3.4. Association with Seabirds, Tuna, and Other Fishes. The Spinner Dolphin was the only species seen with birds (Terns) and Tuna. Out of the 74 sightings of Spinner Dolphins, almost 70\% were recorded as being associated with Yellowfin Tuna. The Spinners follow the Yellowfin Tuna, not vice versa. This association is due to large Yellowfins feeding in large aggregations which in turn help the dolphins to capture prey easily. This was intimated by a fisher. On occasions Spinner Dolphins were seen associated with sea birds. This was mainly with bridled tern (Sterna anaethetus) and greater crested tern (Sterna bergii).

The abundance and diversity of cetaceans around Trincomalee bay and its adjacent waters were remarkable (Table 1, Figure 4). It is well known that habitat diversity is directly correlated with species diversity. The Trincomalee canyon with its multiple heads and the outfall of the largest river in Sri Lanka, bringing in nutrient rich water, provide a wide variety of cetacean habitat types within a small geographic area, with shallow waters in Koddiyar bay and Thambalagam bay to deep waters adjacent to land. The monsoon adds another layer of complexity with upstream and downstream eddies affecting productivity and shifting spatially with season. During the months of the monsoon the river plume stretches to about eight nautical miles out to the open sea, from the outfall. Large groups of marine organisms and sea bird aggregate to feed during that period. At the beginning of both Southwest monsoon season (MaySeptember) and Northeast monsoon (December-February) a higher number of sightings were recorded (Table 1).

The cetacean community of Trincomalee is dominated by schools of Spinner Dolphins. They were very active all the time and always were observed in groups which comprised a few hundred individuals. They seemed to prefer living associated with other species of marine fauna. According to Findlay et al. [10] the offshore distribution of small cetaceans appears to be determined by water depth, possibly through the distribution of principal prey and the inshore distribution 
is determined by water temperature. O'Callagan and Baker [11] suggest future studies on schooling fish populations and its seasonality may give results that are reflected in the seasonality of the cetacean community.

3.5. Threats. There are several threats to cetaceans in the country. As the human population has increased and the economy has faltered a greater reliance upon fisheries has evolved, resulting in an increased number of by-catches and direct catches. In some areas such as Peru, Sri Lanka, and the Philippines, where artisanal gillnetting has caused the deaths of large numbers of small cetaceans, markets have emerged for cetacean meat, leading to directed hunts [12], as small cetaceans meat is considered a highly palatable cheap source of protein amongst the fishers. Studies carried out on dolphin catches in Sri Lanka by Dayaratne and Joseph [13] and Ilangakoon [14] state that small cetaceans are killed off the west, south-west, and south coast of Sri Lanka, and Stenella longirostris appeared to be the most abundantly caught species. As such, the killing of small cetaceans is evidently taking place to date in the waters of Trincomalee bay. On several occasions small cetaceans with severed flukes were observed in the waters of Trincomalee bay and its adjacent waters. Incidentally, during the period of study several fishers were apprehended by local law enforcement agencies, with small cetacean meat. The fisher in the East coast of Sri Lanka land small cetacean's if they are bycatch, dolphins are targeted when other species of fish are scarce and they help cover the cost of fishing such as fuel. The meat is sold for human consumption or as bait for shark long line fishing, as dolphin meat does not easily disintegrate in water and the blood helps to attract sharks.

After the end of the 30-year long terrorist war, there has been a sudden surge of settlement in the coastal areas of the country; as such this has resulted in the overexploitation and destruction of marine resources by the use of multigear fishing implements that target several species, the use of moxy nets to catch ornamental fish, the use of synthetic gill nets that are death traps for turtles and small cetaceans, and the use of push nets and dragnets that are detrimental to many coastal ecosystems and organisms continue with negative long-term impacts on the marine ecosystem. Therefore the need to focus more effort on surveying and assessing marine mammal population is significant.

\section{Conclusion}

The data presented here gives only a brief overview of the cetacean community of Trincomalee bay and its adjacent waters. However, the area appears to be an important habitat used by populations of many species of cetaceans, which may prove to be semiresident, and an area intermittently used by other cetaceans that pass by including rare species. Baseline data of the cetaceans are required for good management practice.

Further environmental data such as sea surface temperature (SST), water depth with location would provide important information for management, particularly where cetaceans move across shipping lanes. Monitoring cetacean population is crucial for understanding the changes over time, including the extent of geographic occurrence and shifts in species composition [15]. Use of dedicated research platforms, better photographic identification analysis, and samples collection such as biopsy would provide data on cetacean's seasonal variation in abundance and distribution.

\section{Conflict of Interests}

The authors declare that there is no conflict of interests regarding the publication of this paper.

\section{Acknowledgment}

The authors would like to thank everyone who helped throughout the research and preparation of the paper.

\section{References}

[1] MOE, The National Red List 2012 of Sri Lanka; Conservation Status of the Fauna and Flora, Ministry of Environment, Colombo, Sri Lanka, 2012.

[2] A. D. Ilangakoon, "Taxonomy and current status of marine mammals in Sri Lanka," in Fauna of Sri Lanka: Status of Taxonomy, Research and Conservation, C. N. B. Bambaradeniya, Ed., pp. 302-308, The World Conservation Union, Government of Sri Lanka, Colombo, Sri Lanka, 2006.

[3] B. Swan, An Introduction to the Coastal Geomorphology of Sri Lanka, National Museums of Sri Lanka, Colombo, Sri Lanka, 1983.

[4] H. B. Stewart, F. P. Shepard, and R. S. Dietz, "Submarine canyons off Eastern Ceylon," Geological Abstracts America, vol. 82, article $197,1964$.

[5] A. Rajasooriya, N. Perera, and M. Fernando, "Status of coral reefs in Trincomalee, Sri Lanka," in Coral Reef Degradation in the Indian Ocean, Status Report, D. Souther and O. Linden, Eds., pp. 97-103, 2005.

[6] R. L. Pitman and C. Stinchcomb, "Rough-toothed dolphins (Steno bredanensis) as predators of Mahimahi (Coryphaena hippurus)," Pacific Science, vol. 56, no. 4, pp. 447-450, 2002.

[7] R. C. Anderson, "Observations of cetaceans in the Maldives, 1990-2002," Journal Cetacean Research Management, vol. 7, no. 2, pp. 119-135, 2005.

[8] W. F. Perrin and A. A. Hohn, "Pantropical spotted dolphin Stenella attenuate," in Handbook of Marine Mammals, S. H. Ridgway and R. Harrison, Eds., vol. 5 of The First Book of Dolphins, pp. 71-98, Academic Press, London, UK, 1994.

[9] L. T. Ballance and R. L. Pitman, "Cetaceans of the Western Tropical Indian Ocean: distribution, relative abundance, and comparisons with cetacean communities of two other tropical ecosystems," Marine Mammal Science, vol. 14, no. 3, pp. 429459, 1998.

[10] K. P. Findlay, P. B. Best, G. J. B. Ross, and V. G. Cockcroft, "The distribution of small odontocete cetaceans off the coasts of South Africa and Namibia," South African Journal of Marine Science, vol. 12, no. 1, pp. 237-270, 1992.

[11] T. M. O'Callagan and C. S. Baker, "Summer cetacean community, with particular reference to Bryde's whales in the Haruraki Gulf, New Zealand," Doc Science Internal Series 55, Department of Conservation, Wellington, New Zealand, 2002. 
[12] R. R. Reeves, B. D. Smith, E. A. Crespo, and G. Notarbartolo di Sciara, Dolphins, Whales and Porpoises: 2002-2010 Conservation Action Plan for the World's Cetaceans, IUCN/SSC Cetacean Specialist Group, IUCN, Gland, Switzerland, Cambridge, UK, 2003.

[13] L. P. Dayaratne and L. Joseph, A Study on Dolphin Catches in Sri Lanka, Bay of Bengal Programme, Madras, India, 1999.

[14] A. Ilangakoon, "Species composition, seasonal variation, sex ratio and body length of small cetaceans caught off the west, south-west and south coasts of Sri Lanka," Journal of the Bombay Natural History Society, vol. 94, no. 2, 1997.

[15] G. Bearzi, M. Costa, E. Politi, S. Agazzi, N. Pierantonio, and D. Tonini, "Cetacean records and encounter rates in the northern Adriatic Sea during the years 1988-2007," Annales, Series Historia Naturalis, vol. 19, pp. 145-150, 2009. 

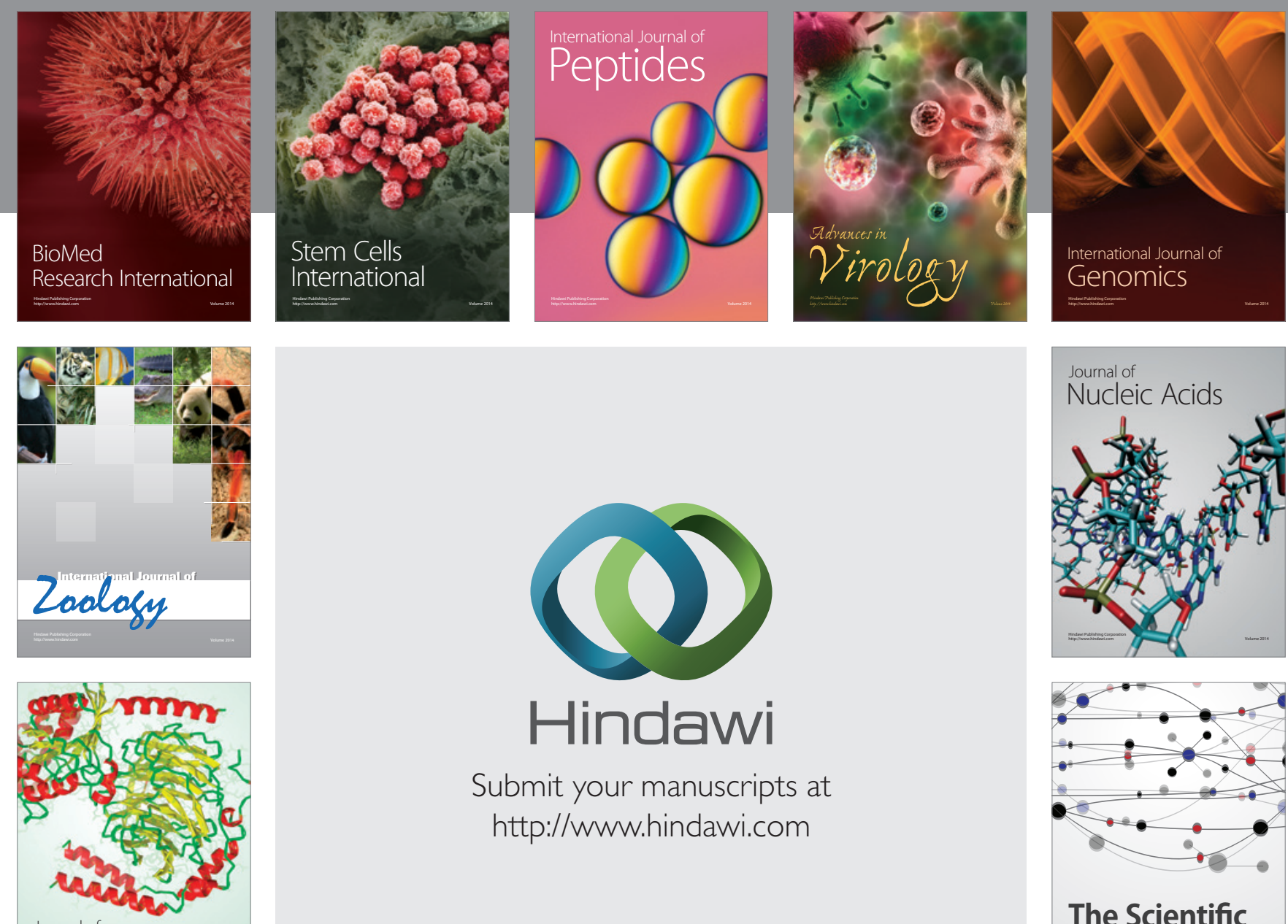

Submit your manuscripts at

http://www.hindawi.com

Journal of
Signal Transduction
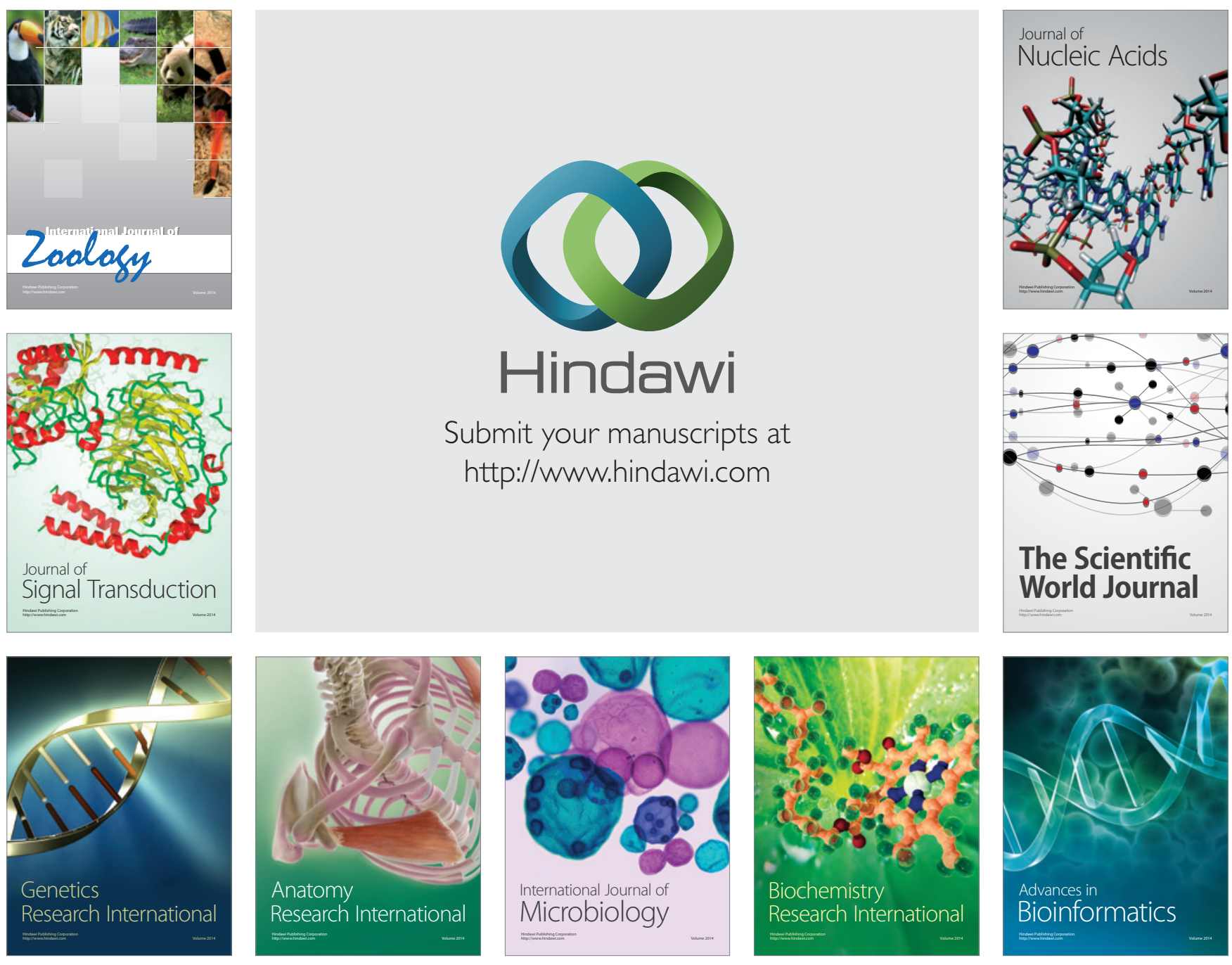

The Scientific World Journal
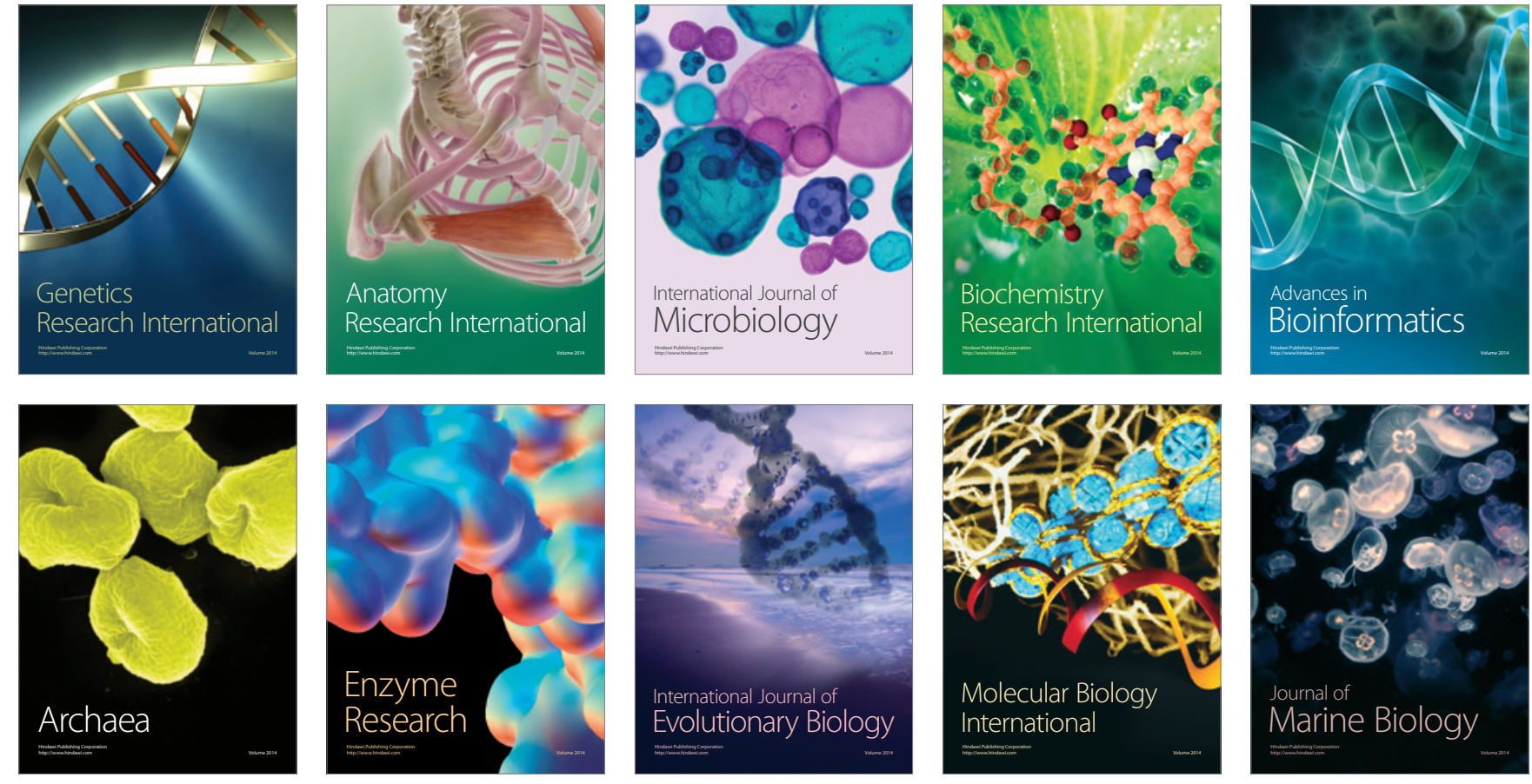